\title{
IMPACT OF REFUGEE AND MIGRATION CRISIS ON GREEK TOURISM DESTINATIONS
}

\author{
Rouska KRASTEVA \\ Tourism Department, Faculty ot Economics, SWU "Neofit Rilski", Blagoevgrad, Bulgaria
}

\begin{abstract}
The refugee and migrants movement is a historical phenomenon, driven by global forces and having effects on politics, economy and community of the hosting countries. Especially, the refugee and migrant stream of recent years - 2015 and 2016, has a decisive impact on the demand of touristic services on the Greek islands in northern Aegean Sea. The aim of the study is to examine and to compare the expected and the real impact of the current migrant and refugee crisis on the tourism, social and economic sphere on the islands according to the interviewed hoteliers on islands Lesvos and Chios. Crucial to maintaining the good image of these tourism destinations, is the good coordination between the local communities, local authorities and those at national, regional and international level on marketing, economic and regional policy.
\end{abstract}

Keywords: refugee crisis, migration crisis, Greek islands, impacts on tourism.

\section{Introduction}

There are durable actual international trends affecting migration in the modern world, like growth of illegal migration, growth of forced migration, increasing demographic significance of international migration and globalization of world migration processes (Tsoneva, p. 132). These trends seem to have impact to the islands Lesvos and Chios, as tourism destinations. The examine islands situated in North Aegean Sea and due to their favorable location near the coast of Turkey became a bridge to Western Europe for large numbers of migrants and refugees, coming from Syria, Afghanistan, Bangladesh, Eritrea, Sierra Leone etc. Their presences seem to change the touristic image of the destinations. According to the results of the questionnaire which examines the impact of migrant and refugee crisis on Greek tourism industry from January-February 2016, with these from September-October among hoteliers in the summer resorts of the two island, in some situations there is a significant difference between the expected and the real impact of the current migrant and refugee crisis on the tourism, social and economic sphere on the islands. 


\section{Literature review}

Migration is for various reasons, abandoning of native land. The reasons that lead to the phenomenon of migration vary and depend on the conditions prevailing in the particular period in the areas of residence. In the scientific literature migration takes the separation of internal and external, voluntary and compulsory, primary and secondary, conservative and radical, complete and partial.

According to $J$. Isaac (1949, p. 379) possible reasons that make migrants to move, are political, social, economic and demographic changes in the country of origin. For the ethnologist Robert Gordon Latham (Encyclopedia Papyrus Larousse Britannica, 1990) primary migration covers the movement of such population groups, which aim absorption of uninhabited and unused areas as secondary migration means contact to him that migrates with the relevant indigenous population. Secondary migration movements are of slower rate, due to the response of another national group against new arrivals. Migration flows of this kind, most times are accompanied by violence, which leads to either merge the old with the new population, or disappearance of one of the two populations. R. Mayo-Smith splits migration to internal and external. The first is defined as movement within the one or the other country, and the second covers the movement of residents of a country within its borders. According to $J$. Isaac the reason for migration, both voluntary and compulsory, is the experience of those who emigrate to dispose of various factors that oppress them life and personal and therefore these two categories represent two different sides of the same phenomenon. $W$. Petersen distinguishes two types of migration, conservative and radical according to the consequences that this migration is causing to the social and financial situation of receiving countries. International law distinguishes migrants from refugees, people fleeing to find refuge from war, natural disaster, or political persecution (Goldstein, and Pevehouse, p. 434). Migration has a dynamic quality (Migration, Sociological studies 1969) and covers the cases where the decision to migrate is taken freely by the individual concerned, because of personal convenience and without intervention by an external compelling factor.

Dimitrov P. (2007, p. 2, 19) talks about that in unfavorable tourism conjuncture the supply structure is deteriorating, the manufacturing base cannot access the optimum, as well as the labor resources, the competition is increasing and the final financial results are worsen. In terms of demand, the picture of tourism conjuncture has strong relationship with the demographic trends and sociocultural changes. He also notes that in view of the fact that tourism is not a vital service, tourist behavior is highly vulnerable to psychological and social influences, personal sensitivities and short-term reactions. If the image of a destination just in one link of the chain is bad then the all perception suffers.

Another researcher, Hein de Haas (2008, p. 3) notes among the main reasons why it is hard to make general explanations about the causes and the consequences of migration are the 
diversity and complexity of the phenomenon, as well as the difficulty of separating migration from other socio-economic and political processes. Describing the historical-structural theory he notes that "historical-structuralists postulate that economic and political power is unequally distributed among developed and underdeveloped countries, that people have unequal access to resources, and that capitalist expansion has the tendency to reinforce these inequalities. Instead of modernizing and gradually progressing towards economic development, underdeveloped countries are trapped by their disadvantaged position within the global geopolitical structure".

According to Goldstein and Pevehouse (2011, p. 436) "refugees are both a result of international conflict and a source of conflict". Ekberg (1999, p. 412) notes that "immigration may affect the income conditions of the native population in many ways". There may be effects on the markets, on employment opportunities for natives and on economic growth.

The World Bank (2013) has studied the impact of the Syrian conflict in the economic and social life in Lebanon and had found that the conflict and the open border policy are pronounced in the services trade sector and in particular to the large tourism sector - "with the number of international visitors having steadily declined since 2010 ”.

Threats and uncertainty have always been a part of human existence as Ostrowska (2014, p.75, 78) notes. Nowadays, in a global economy integrated by modern infrastructure and telecommunications, by high and good quality of education when communication, work procedures and quality of life seems to be better than a century ago, motivation is still according to Lebeau (Dougherty, and Pfaltzgraff, 2004, p. 335) a key moment in the crisis behavior. Leaders are convinced that they need to act in so far as responding to interests and actions of other actors who are obstacle to the success of their policy. As a result, the leaders may be neglected or omitted information, which contains the reverse signs relative to the direction of action they have undertaken, in order to support their predetermined goals. Fair or not it happens, and today refugee or immigrants live in "camps" in the examined regions, that have become long-term neighborhoods, as the one in Jordan, Lebanon and the Palestinian territories of Gaza and the West Bank (Goldstein, and Pevehouse, 2011, p. 436).

\section{Methodological framework of the survey}

In this paper the researcher works on a case study, concern the Greek islands Chios and Lesvos and the impact of the refugee and migration crisis on these tourism destinations. Like a result of these observations the researcher tries to make some generalizations on the topic. This is inductive approach. At the same time the research is based in some theories (deductive approach). Finally the methodology used is a combination of inductive and deductive approach. The instrument of the inductive approach is the questionnaire. The research was conducted by the author from September to October 2016. The questionnaire was distributed to hoteliers in 
the summer resorts of the two islands - on island Lesvos and island Chios, which are two of the islands through which pass a great number of refugees and immigrants in order to continue their road to the other countries of Europe. According to data taken from the Hellenic Chamber of Hotels the total number of registered hotels in the examined islands is approximately 178 . The sample size of the research in this period of time is 168 hotels, an appropriate size for this research, taking into account the table for determining the minimum returned sample size for given population size (Bartlett, Kotrlik, and Higgins, 2001).

\section{Analysis and evaluation of results}

To the question "In your opinion which will be the impact of refugee and migrants crisis on the local economy of the Greek islands?" the majority of the interviewed hoteliers on island Lesvos $81.1 \%$ and island Chios $83.58 \%$ share the pessimistic opinion that the income of enterprises as a whole in the business sector will decrease. As about the income of tourism enterprises specifically, one $10.89 \%$ of the hoteliers on island Lesvos and one $11.94 \%$ of them on island Chios think that they will decrease. Interesting are the results of these almost $12 \%$ that answer "Only the impact of tourism enterprises will increase" or "The income of enterprises in general will increase", noting that they will achieve this with the stays and shopping of the refugees and immigrants themselves, as well as with the NGO's and reporters and photographers from all over the world that have interest, doing their work to visit and stay on the islands. When the hoteliers were asked in September-October which is their opinion about the real situation on the islands the results on island Lesvos were similar with the expectations they had in January-February, but for island Chios there are differences in all aspects - with most interesting result the one that shows that $43 \%$ less respondents than in January-February think that the income of enterprises in general has decreased.

\section{Table 1.}

Impact of refugee and migrant crisis on the local economy of the Greek islands

\begin{tabular}{|l|l|l|l|l|l|}
\hline \multirow{2}{*}{ № } & \multirow{2}{*}{ Answers } & \multicolumn{2}{l|}{ Island Lesvos } & \multicolumn{2}{l|}{ Island Chios } \\
\cline { 3 - 6 } & & $\begin{array}{l}\text { Jan.-Febr. } \\
\mathbf{2 0 1 6}\end{array}$ & $\begin{array}{l}\text { Sept.-Oct. } \\
\mathbf{2 0 1 6}\end{array}$ & $\begin{array}{l}\text { Jan.-Febr. } \\
\mathbf{2 0 1 6}\end{array}$ & $\begin{array}{l}\text { Sept.-Oct. } \\
\mathbf{2 0 1 6}\end{array}$ \\
\hline 1. & Increase of tourism enterprises income & $4.95 \%$ & $2.97 \%$ & $2.98 \%$ & $8.95 \%$ \\
\hline 2. & Increase of income of enterprises in general & $2.97 \%$ & $5.94 \%$ & $1.49 \%$ & $17.91 \%$ \\
\hline 3. & Decrease of tourism enterprises income & $10.89 \%$ & $2.97 \%$ & $11.94 \%$ & $32.83 \%$ \\
\hline 4. & Decrease of income of enterprises in general & $81.1 \%$ & $84.15 \%$ & $83.58 \%$ & $40.29 \%$ \\
\hline 5. & Other & $0 \%$ & $3.9 \%$ & $0 \%$ & $0 \%$ \\
\hline
\end{tabular}

Source: Krasteva, and Pantelis, 2016.

As regards the impact of refugee and migrants crisis on the local social-demographic physiognomy of the Greek islands there are serious differences from what the hoteliers believed that will happen and what they think that really happened. The most contrasting results concern 
the answer "The number of the permanent population in the settlement of the island remains stable" with some $24.78 \%$ of the hoteliers of island Lesvos and some $25.3 \%$ of them of island Chios given this answer in January-February 2016 and respectively some $66.33 \%$ and $40.29 \%$ in September-October 2016.

Table 2.

Impact of refugee and migrant crisis on the social-demographic physiognomy of the Greek islands

\begin{tabular}{|c|l|l|l|l|l|}
\hline \multirow{2}{*}{ № } & \multirow{2}{*}{ Answers } & \multicolumn{2}{l|}{ Island Lesvos } & \multicolumn{2}{l|}{ Island Chios } \\
\cline { 3 - 6 } & & $\begin{array}{l}\text { Jan.-Febr. } \\
\mathbf{2 0 1 6}\end{array}$ & $\begin{array}{l}\text { Sept.-Oct. } \\
\mathbf{2 0 1 6}\end{array}$ & $\begin{array}{l}\text { Jan.-Febr. } \\
\mathbf{2 0 1 6}\end{array}$ & $\begin{array}{l}\text { Sept.-Oct. } \\
\mathbf{2 0 1 6}\end{array}$ \\
\hline 1. & $\begin{array}{l}\text { Increase of permanent population in the } \\
\text { settlements of the island }\end{array}$ & $22.78 \%$ & $25.74 \%$ & $19.41 \%$ & $29.85 \%$ \\
\hline 2. & $\begin{array}{l}\text { The number of the permanent population in } \\
\text { the settlement of the island remains stable }\end{array}$ & $24.78 \%$ & $66.33 \%$ & $25.3 \%$ & $40.29 \%$ \\
\hline 3. & $\begin{array}{l}\text { Decrease of the permanent population in the } \\
\text { settlements of the island }\end{array}$ & $19.8 \%$ & $0 \%$ & $22.3 \%$ & $0 \%$ \\
\hline 4. & $\begin{array}{l}\text { Young people stay and work in their } \\
\text { hometown }\end{array}$ & $15.8 \%$ & $7.92 \%$ & $17.9 \%$ & $29.85 \%$ \\
\hline 5. & None of the above & $16.8 \%$ & $0 \%$ & $14.9 \%$ & $0 \%$ \\
\hline
\end{tabular}

Source: Krasteva, and Pantelis, 2016.

The fear of decreasing of the permanent population in the settlements of the islands, expressed from $19.8 \%$ of the respondents on island Lesvos and $22.3 \%$ on island Chios was ungrounded. In the same levels (but a little bit higher for island Chios) with the one from January-February are the percentages for September-October about increasing the permanent population in the two islands, and about the staying and working of young people in their hometown.

The analysis about the impact of refugee and migrant crisis on the regional policy and the natural environment of the examined Greek islands for the period January-February 2016, shows that hoteliers from both island Lesvos and island Chios think that there will be negative effects on the natural environment and the infrastructure of the islands, as a result of the great number of arrivals and long stay in terms of time of migrants and refugees - some $83.1 \%$ from the respondents on island Lesvos and some $82 \%$ of them on island Chios. When the same questions were asked in September-October 2016 the results were significant lower $50.5 \%$ on island Lesvos and $20.91 \%$ on island Chios. The expectations about sponsoring infrastructure projects both from the state on the one hand and from the local municipalities on the other, remains low to insignificant - from 1,98\% the lowest to 4,95\% the highest in January - February 2016 and from $11.88 \%$ to $14.91 \%$ in September-October 2016. Almost 10\% is the percentage of hoteliers that in the winter months believe that the situation will remain unchangeable and there will be no consequences on infrastructure and the natural environment of the areas as a result of the presence of refugees and immigrants, but in autumn a greater number of them, some $24.75 \%$ on Lesvos and 55.23 on Chios share this opinion. 
Table 3.

Impact of refugee and migrant crisis on the regional policy and the natural environment of the Greek islands

\begin{tabular}{|c|l|l|l|l|l|}
\hline \multirow{2}{*}{ № } & \multirow{2}{*}{ Answers } & \multicolumn{2}{l|}{ Island Lesvos } & \multicolumn{2}{l|}{ Island Chios } \\
\cline { 3 - 5 } & & $\begin{array}{l}\text { Jan.-Febr. } \\
\mathbf{2 0 1 6}\end{array}$ & $\begin{array}{l}\text { Sept.Oct. } \\
\mathbf{2 0 1 6}\end{array}$ & $\begin{array}{l}\text { Jan.-Febr. } \\
\mathbf{2 0 1 6}\end{array}$ & $\begin{array}{l}\text { Sept.-Oct. } \\
\mathbf{2 0 1 6}\end{array}$ \\
\hline 1. & $\begin{array}{l}\text { More infrastructure projects sponsored by } \\
\text { the State }\end{array}$ & $4.95 \%$ & $11.88 \%$ & $4.47 \%$ & $14.91 \%$ \\
\hline 2. & $\begin{array}{l}\text { More infrastructure projects sponsored by } \\
\text { the local municipalities }\end{array}$ & $1.98 \%$ & $12.87 \%$ & $2.98 \%$ & $8.95 \%$ \\
\hline 3. & $\begin{array}{l}\text { Negative effects on the natural environment } \\
\text { and the infrastructure of the island }\end{array}$ & $83.1 \%$ & $50.5 \%$ & $82 \%$ & $20.91 \%$ \\
\hline 4. & The situation remains as it was & $9.9 \%$ & $24.75 \%$ & $10.44 \%$ & $55.23 \%$ \\
\hline
\end{tabular}

Source: Krasteva, and Pantelis, 2016.

To the question about the impact of refugee and migrants crisis on tourism sector of the Greek islands the interviewed in January-February hoteliers answer that they expect for the summer months of 2016 to have lower overnight stays (33.66 \%) and lower visits $(26.73 \%)$ than the summer of 2015. Interesting are the results from these almost $40 \%$ that answer "Another impact" and fill in the questionnaire that they will achieve completeness in the hotel with the stays of the refugees and immigrants themselves, as well as with the NGO's that have interest, doing their volunteer work to visit and stay on the island. But, when the hoteliers were asked in September-October about the real situation for the summer months of 2016 still a great number of them - some $55.44 \%$ on island Lesvos and $73.37 \%$ on island Chios declare that the overnight stays and visits are lower than the one in the previous summer. As during the winter months the respondents didn't choose the answers "The number of overnight stays will increase", "The number of overnight stays will remain the same as last year", "The number of visits will increase", some months later, in September-October 2016 about 27.69\% in island Lesvos declare that overnight stays and visits were higher during the summer of 2016 in comparison with the summer of 2015, and almost the same percent in island Chios says that the overnight stays remain the same as last year, but still no one thinks that the overnight stays and visits were higher during the summer of 2016 in comparison with the previous summer.

Table 4.

Impact of refugee and migrant crisis on tourism sector of the Greek islands

\begin{tabular}{|l|l|l|l|l|l|}
\hline \multirow{2}{*}{ № } & \multirow{2}{*}{ Answers } & \multicolumn{2}{|l|}{$\begin{array}{l}\text { \% of hoteliers on Island } \\
\text { Lesvos }\end{array}$} & \multicolumn{2}{l|}{$\begin{array}{l}\text { \%of Hoteliers on Island } \\
\text { Chios }\end{array}$} \\
\cline { 3 - 6 } & & $\begin{array}{l}\text { Jan.-Febr. } \\
\mathbf{2 0 1 6}\end{array}$ & $\begin{array}{l}\text { Sept.-Oct. } \\
\mathbf{2 0 1 6}\end{array}$ & $\begin{array}{l}\text { Jan.-Febr. } \\
\mathbf{2 0 1 6}\end{array}$ & $\begin{array}{l}\text { Sept.-Oct. } \\
\mathbf{2 0 1 6}\end{array}$ \\
\hline 1. & $\begin{array}{l}\text { The number of overnight stays is lower than } \\
\text { these of last year }\end{array}$ & $33.66 \%$ & $26.73 \%$ & $44.78 \%$ & $33.11 \%$ \\
\hline 2. & $\begin{array}{l}\text { The number of visits is lower than these of } \\
\text { last year }\end{array}$ & $26.73 \%$ & $28.71 \%$ & $17.91 \%$ & $40.26 \%$ \\
\hline 3. & $\begin{array}{l}\text { The number of overnight stays is higher } \\
\text { than these of last year }\end{array}$ & $0 \%$ & $27.72 \%$ & $0 \%$ & $0 \%$ \\
\hline 4. & $\begin{array}{l}\text { The number of overnight stays remains the } \\
\text { same as last year }\end{array}$ & $0 \%$ & $13.87 \%$ & $0 \%$ & $26.63 \%$ \\
\hline
\end{tabular}




\begin{tabular}{|l|l|l|l|l|l|}
\hline 5. & $\begin{array}{l}\text { The number of visits is higher than these of } \\
\text { last year }\end{array}$ & $0 \%$ & $2.97 \%$ & $0 \%$ & $0 \%$ \\
\hline 6. & Another & $37.31 \%$ & $0 \%$ & $37.31 \%$ & $0 \%$ \\
\hline
\end{tabular}

Source: Krasteva, and Pantelis, 2016.

According to the answers given in the period January-February divided seems to be the opinion of the hoteliers on islands Lesvos and Chios, about the expected impact of refugee and migrant crisis on the island as a tourism destination, as some $48.51 \%$ of the hoteliers from island Lesvos and some $49.25 \%$ of them on island Chios think of positive impact and specially "That the island will become a world famous destination" and some $49.50 \%$ of the hoteliers from island Lesvos and some $46.26 \%$ of them on island Chios gave answers that show a pessimistic point of view - "That the island will be defamed".

In the same question, but some months later the results are totally different on island Chios, as now the majority of the share the opinion that the refugee and migrant crisis will lead to the defamation of the island. On island Lesvos some $44.55 \%$ of the respondents are still pessimists about the development of the island as a tourism destination and the same percentage of them think that the situation remains as it was before the refugee and migration crisis.

Table 5.

Impact of refugee and migrant crisis on island as a tourism destination

\begin{tabular}{|l|l|l|l|l|l|}
\hline \multirow{2}{*}{ № } & \multirow{2}{*}{ Answers } & \multicolumn{3}{l|}{ Island Lesvos } & \multicolumn{2}{l|}{ Island Chios } \\
\cline { 3 - 6 } & & $\begin{array}{l}\text { Jan.-Febr. } \\
\mathbf{2 0 1 6}\end{array}$ & $\begin{array}{l}\text { Sept.-Oct. } \\
\mathbf{2 0 1 6}\end{array}$ & $\begin{array}{l}\text { Jan.-Febr. } \\
\mathbf{2 0 1 6}\end{array}$ & $\begin{array}{l}\text { Sept.-Oct. } \\
\mathbf{2 0 1 6}\end{array}$ \\
\hline 1. & $\begin{array}{l}\text { The island become a world famous } \\
\text { destination }\end{array}$ & $48.51 \%$ & $10.90 \%$ & $49.25 \%$ & $11.95 \%$ \\
\hline 2. & Defamation of island & $49.50 \%$ & $44.55 \%$ & $46.26 \%$ & $83.58 \%$ \\
\hline 3. & Nothing of above & $1.98 \%$ & $44.55 \%$ & $4.47 \%$ & $4.47 \%$ \\
\hline
\end{tabular}

Source: Krasteva, and Pantelis, 2016.

\section{Conclusions and Recommendations}

Finally, the survey results indicate that:

1. The refugee and migrant crisis contribute for an unfavorable tourism conjuncture on the Greek islands of the north Aegean Sea.

2. In some aspects of the study, like the demographic physiognomy and the impact on tourism there is a significant difference between the expectations of the hoteliers on both Lesvos and Chios about the impact of the refugee and migrant crisis on the islands as tourism destinations and the estimation they made about the real situation there.

3. Concerning other aspects of the study, like the impact on economy and regional policy and the impact on natural environment, that has the refugee and migrants crisis, on the one island there are differences between the expectations expressed in January-February 
and the real situation about the summer months, expressed in September-October and in the other there are more similarities and the opposite for the different questions.

Of course these results couldn't be generalized as a theory yet, because of the local character of the research and the short term of study. Through the centuries states have been increasingly working together to regulate population movements and provide refugee relief through regional and global negotiations and international coordination (Venturas, p. 2). These movements are a global historical phenomenon, but for the Greek islands they are a new challenge in a difficult period of financial crisis, that needs a good and adequate approach to bring positive effects on the tourism industry, the local economy and the local community without violating human rights and freedoms. Crucial to maintaining the good image and identifying these islands known as tourist destinations, which are offering high quality and professionalism of tourism servises is the good coordination between the local communities, local authorities and those at regional, national and international level on marketing, economic environmental and tourism policy. They should establish the balance needed in order to contribute to positive results in the touristic sector of the region.

\section{Bibliography}

1. Bartlett, J., Kotrlik, J., and Higgins, Ch. (2001). Organizational Research: Determining appropriate sample size in survey research. Information Technology, Learning and Performance Journal, Vol. 19, No. 1, p. 1.

2. Dimitrov, P. (2007). Conjuncture in the tourism industry. Blagoevgrad: University publ. "Neofit Rilski".

3. Dougherty, J.E., and Pfaltzgraff, Jr., R.L. (Editors), (2004). Contending Theories of international relations, A comprehensive Survey. Sofia, Atika publications.

4. Ekberg, J. (1999). Immigration and the public sector: Income effects for the native population in Sweden. Journal of Population Economics, Vol. 12, p. 411-430.

5. Encyclopedia Papyrus Larousse Britannica, Vol. 41, Publ. Papyrus, 1990.

6. Goldstein, J.S., and Pevehouse, J.C. (2010-2011). International Relations. Boston: Pearson Publications.

7. Hein de Haas (2008). Migration and development: a theoretical perspective. International Migration Institute, University of Oxford.

8. Isaac, J. (1949). Migration Potential and prospects. Journal Population Studies, Vol. II, no. 4.

9. Jackson, J.A. (Edited) (1969). Migration. Sociological Studies, Vol. 2. Cambridge: University Press, p. 1-2, Available at https://books.google.bg/books?id=_kAUEhyYqE8 $\mathrm{C} \& p g=\mathrm{PA} 12 \& \operatorname{lpg}=\mathrm{PA} 12 \& \mathrm{dq}=\mathrm{J} .+\mathrm{Isaac}+$ migration $\&$ source $=\mathrm{bl} \&$ ots $=5 \mathrm{votzw} 1 \mathrm{Rgz} \&$ sig $=2$ 
750wXzAiGsPm5faE1 gqutgjrcc\&hl=bg\&sa=X\&ved=0ahUKEwjUka_fzffLAhWpYJoK HQUvAz8Q6AEILTAD\#v=onepage\&q=J.\%20Isaac\%20migration\&f=false.

10. Ostrowska, M. (2014). Risk management in crisis situations. Forum Scientiae Economia, Vol. 2, № 2, p. 75-84. Retrieved October 20, 2016, from http://www.wsb.edu.pl/ container/Wydawnictwo/Do\%20pobrania/6.-ostrowska.pdf.

11. Tsoneva, M. (2011). Europe and the Mediterranean. Blagoevgrad: University publ. "Neofit Rilski".

12. Venturas, L. (Editor) (2015). International "migration management" in the early cold war. The intergovernmental Committee for European Migration, Publ. University of the Peloponnese.

13. World Bank (2013). Lebanon: Economic and Social impact Assessment of the Syrian conflict-Executive summary. Retrieved March 10, 2016, from http://www.worldbank.org/ content/dam/Worldbank/document/MNA/LBN-ESIA\%20of\%20Syrian\%20Conflict\% 20EX\%20SUMMARY\%20ENGLISH.pdf. 